\title{
DESIGN, ANALYSIS AND COMPARISON OF VARIOUS MATERIALS FOR CONNECTING ROD
}

\author{
Sumant R Balli \\ Mechanical engineering, K.L.E Institute of Technology, Hubli, India \\ Prajwal Shetty \\ Mechanical engineering, K.L.E Institute of Technology, Hubli, India \\ S.C.Sajjan \\ Faculty Department Mechanical Engineering, K.L.E Institute of Technology, Hubli, India
}

Article DOI: https://doi.org/10.36713/epra4760

\begin{abstract}
Connecting rod is engine component which transmits motion from piston to the crankshaft and serves as lever arm. The function of connecting rod is to convert piston's reciprocal movement into rotary motion of the crankshaft. Connecting rod generally made from Carbon steel and Aluminium alloys have been used in recent days and some different materials are finding it's application. The performance connecting rod in automobile engine is influenced by it's design and weight for production of durable, cheaper and light connecting rod, hence optimization and analysis of connecting rod. The $3 D$ model of connecting rod is designed and developed using CATIA V5. In proposed approach different materials compared like Aluminium alloy 7075, Magnesium alloy, Titanium alloys ( Ti -3Al- 2.5V) and beryllium alloy (25) are taken for the analysis of connecting rod and factors like Stress, Strain and Deformation were obtained. The purpose of this study is identify best materials for connecting rod, after analysing at ANSYS APDL 15.0.
\end{abstract}

KEYWORDS : Connecting rod, CATIA V5, ANSYS APDL15.0, Aluminium alloy 7075, Magnesium alloy, Titanium alloy (Ti-3Al-2.5V) and Beryllium Alloy (25).

\section{INTRODUCTION}

For connecting pistons to the crankshaft, the connecting racks are used. The upper end of rod oscillates while lower end or big end rotates. It converts reciprocating motion piston into rotary motion the crankshaft. A combination of axial and bending stresses acts on the rod in operation. The axial stresses are due to gas pressure in the cylinder and inertia force caused by the reciprocating motion. Bending stresses are used due to the centrifugal effects. The rod has an I-beam cross section to give the highest stiffness and minimum weight. The tendency in vehicle development drove the invention and execution of very new material which are light and meet plan prerequisites. Lighter connecting rod helps to diminish lead brought about by force of inertia in engine as it doesn't require big balancing weight of crankshaft. Use of metal matrix composite unable safety increases and progresses that prompts successful utilization of feel and to get high engine power.

It is necessary for designers to find out the stresses present within the connecting rod, to bear the load even in worst situation without failing completely. Hence it is required to analyze the strain intensity, stress concentration and deformation in the piston end of the connecting rod. The specification parameter or measurement of connecting rod is determined based on the working parameter on chosen vehicle. The model of connecting rod components is then designed and finally evaluated by FEA method and result thus obtained will give necessary results of work carried out here. 


\section{EPRA International Journal of Research and Development (IJRD)}

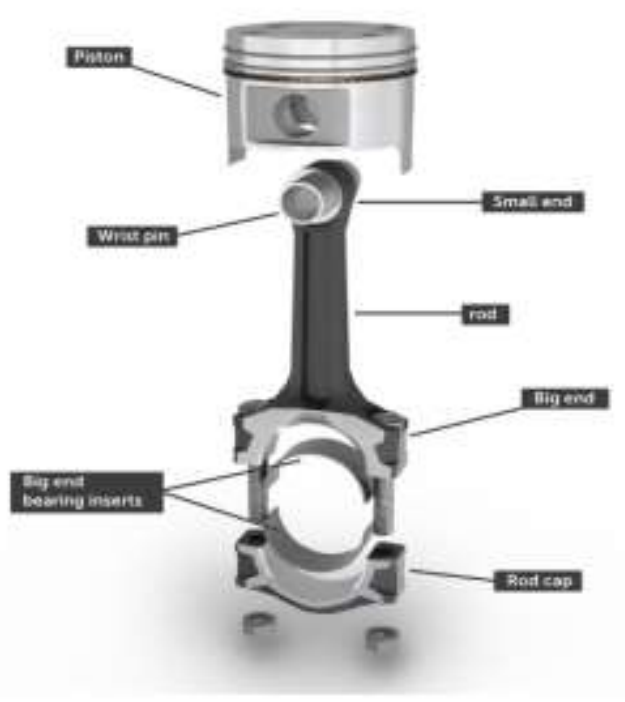

FIG 1: Connecting rod

\section{PROBLEM DEFINTION}

In the proposed approach the main aim is to plan and enhance connecting rod dependent on its material properties by associating connecting rod with various materials like Aluminium alloy 7075, Magnesium alloy, Titanium alloy (Ti$3 \mathrm{~L}-2 \mathrm{~V}$ ) and Beryllium alloy (25). Based on the results of analysis the connecting rod is designed CATIA V5 and analyzed in ANSYS APDL 15.0 software after study, the current material and alternate materials are compared and the optimal performance outcome are recommended for the connecting rod in terms of stresses, strain and deformation.

\section{CALCULATION}

Considering Activa 6G two wheeler vehicle specification for designing of connecting rod.

\section{A. Calculation of Pressure}

Engine type : 4-Stroke air cooled engine

Bore $\times$ Stroke : $47 \times 63.1 \mathrm{~mm}$

Displacement : $109.5 \mathrm{~mm}$

Maximum power : 7.6 bph@8000rpm

Maximum torque : 8.79 N-m@5250 rpm

Compression ratio : 10.0 $\pm 0.2: 1$

Auto ignition temperature : $60^{\circ} \mathrm{F}(288.55 \mathrm{~K})$

Density of petrol : $0.77 \mathrm{~kg} / \mathrm{L}=7.7 \times 10^{-7} \mathrm{~kg} / \mathrm{mm}^{3}$

Molecular weight of petrol : $114.28 \mathrm{~g} / \mathrm{mole}=0.11428$

$\mathrm{kg} /$ mole

Mass $=$ Density $\times$ Volume

$$
\begin{aligned}
& =7.7 \times 10^{-7} \times 109.5 \\
& =0.0843100 \mathrm{~kg}
\end{aligned}
$$

From gas equation

$\mathrm{PV}=\mathrm{MRT}$

$$
\begin{aligned}
\mathrm{P}=\frac{\mathrm{M} R_{S} \mathrm{~T}}{V} & =\frac{0.11 * 72.76 * 288.55}{109.5}=21.11 \mathrm{MPa} \\
B . & \text { Design calculation for Connecting rod }
\end{aligned}
$$

Thickness of flange and web of the section $=\mathrm{t}$

Width of section $B=4 t$

Standard dimension of I-section

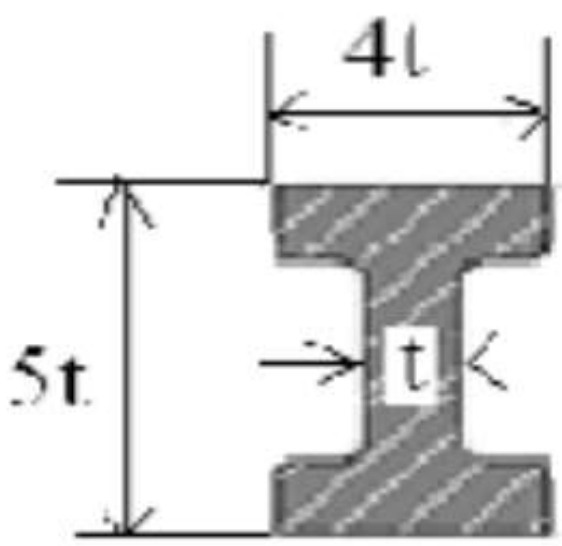

Height of section $\mathrm{H}=5 \mathrm{t}$

Area $\mathrm{A}=2(4 \mathrm{t} \times t)+(3 t \times t)=11 t^{2}$

Moment of inertia of section about $\mathrm{X}$-axis

$I_{x x}=\frac{1}{12} \times 4 t(5 t)^{3}$

$$
=\frac{419}{12}\left(t^{4}\right)
$$

Moment of inertia of section about $\mathrm{Y}$-axis

$I_{y y}=\frac{2}{12} \times t \times(4 t)^{3}+\frac{1}{12}(3 t)^{3}$

$$
=\frac{131}{12}\left(t^{4}\right)
$$

$\frac{I_{x x}}{I_{y y}}=3.2$

Length of connecting rod $(\mathrm{L})=2$ times the stroke $\mathrm{L}=2 \times 63.1=126.2 \mathrm{~mm}$

Total force acting $\mathrm{F}=F_{p}-F_{i}$

$$
\begin{aligned}
F_{p} & =\frac{\Pi}{4} \times d^{2}=\frac{\Pi}{4} \times 63.1^{2} \times 10.55 \\
& =32991.42 \mathrm{~N} \\
F_{i} & =m \omega^{2} r\left(\cos \theta+\frac{\cos 2 \theta}{2}\right) \\
\omega & =2 \frac{\Pi N}{60}=2 \times \Pi \times \frac{8000}{60}=837.76 \mathrm{rad} / \mathrm{s}
\end{aligned}
$$

Crank radius $=\frac{46.5}{2}=23.25 \mathrm{~mm}$

$\mathrm{n}=\frac{l}{r}=\frac{126.2}{23.25}=5.43 \mathrm{~mm}$

$F_{i}=0.084322 \times 837.76^{2} \times 23.25 \times 10^{-3} \times\left(1+\frac{1}{5.43}\right)$

$F_{i}=1629.36 \mathrm{~N}$

$F=F_{p}-F_{i}$

$$
=32991.42-1629.36
$$

$\mathrm{F}=31362.06 \mathrm{~N}$

Buckling load $W_{B}=$ Maximum gas force $\times$ FOS

$$
\begin{aligned}
& W_{B}=\frac{\sigma_{c} \times A}{1+\alpha\left(\frac{L}{K_{x x}}\right)^{2}} \\
& K_{x x}=\sqrt{\frac{I_{x x}}{A}}=\sqrt{\frac{34.91 t^{4}}{11 t^{2}}}=1.78 \mathrm{t} \\
& \alpha=\frac{\sigma_{c}}{\Pi^{2} E}=\frac{160}{\Pi^{2} \times 45}=3.6025 \times 10^{-4}
\end{aligned}
$$

$R_{\text {specific }}=\frac{R_{x}}{M W}=\frac{8.3143}{0.114228}=72.786$ 


\section{EPRA International Journal of Research and Development (IJRD)}

- Peer Reviewed Journal

Hence we use M12 size bolt.

$W_{B}=\frac{160 \times 11 t^{2}}{1+3.6025 \times 10^{-4}\left(\frac{126.2}{1.78 t}\right)}$

$31362.06=\frac{160 \times 11 t^{2}}{1+3.6025 \times 10^{-4}\left(\frac{126.2}{1.78 t}\right)}$

$\mathrm{t}=4.41 \mathrm{~mm}$

Width $\mathrm{B}=4 \mathrm{t}=4 \times 4.41=17.64 \mathrm{~mm}$

Height $\mathrm{H}=5 \mathrm{t}=5 \times 4.41=22.05 \mathrm{~mm}$

Area $\mathrm{A}=11 t^{2}=11 \times 4.41^{2}=213.92 \mathrm{~mm}^{2}$

Height at piston end $H_{1}=0.825 \mathrm{H}$

$$
=0.825 \times 22.05
$$

$$
=18.191 \mathrm{~mm}
$$

Height at crank end $H_{2}=1.175 \mathrm{H}$

$$
\begin{aligned}
& =1.175 \times 22.05 \\
& =25.9087 \mathrm{~mm}
\end{aligned}
$$

Diameter of piston $\mathrm{D}=47 \mathrm{~mm}$

\section{Design of small end}

Load on piston pin or small end

$F_{p}=d_{p} l_{p} \times P_{b p}$

$d_{p}=$ Inner diameter of small end

$l_{p}=$ Length of piston pin $=1.5 d_{p}$

$P_{b p}=$ Bearing pressure $=10 \mathrm{MPa}$

$1032991.42=1.5 d_{p} \times d_{p} \times 10$

$d_{p}=46.89 \cong 47 \mathrm{~mm}$

$L_{p}=1.5 \times 47=70.5 \mathrm{~mm}$

Outer diameter of small end $=d_{p}+2 t_{b}+2 t_{m}$

$=47+(2 \times 3)+(2 \times 5)$

$=63 \mathrm{~mm}$

\section{Design of big end}

Load on crank pin $F_{p}=$ Projected area $\times$ bearing pressure $F_{p}=d_{c} l_{c} \times P_{b c}$

$32991.42=1.25 d_{c} \times d_{c} \times 7.5$

$d_{c}=59.32 \cong 60 \mathrm{~mm}$

$L_{c}=1.25 d_{c}=1.25 \times 60=75 \mathrm{~mm}$

Outer end of crank end $=d_{c}+2 t_{b}+2 t_{m}+2 d_{b}$

Where,

Thickness of bush $t_{p}=3-5 \mathrm{~mm}$

Marginal thickness $t_{m}=5-10 \mathrm{~mm}$

Marginal thickness bolt $=3-6 \mathrm{~mm}$

$=60+(2 \times 4)+(2 \times 5)+(2 \times 4)$

$=86 \mathrm{~mm}$

\section{Design of bolt}

Force on bolt $=\frac{\Pi}{4} \times\left(d_{c b}\right)^{2} \times \sigma_{t} \times n_{b}$

Where,

$d_{c b}=$ Core diameter of bolts

$\sigma_{t}=$ Allowable tensile stress of the bolt $=12 \mathrm{MPa}$

$n_{b}=2$ bolts

$\mathrm{F}=\frac{\Pi}{4} \times\left(d_{c b}\right)^{2} \times 12 \times 2$

$\mathrm{F}=18.85 d_{c b}^{2}$

$1629.36=18.85 \times d_{c b}^{2}$

$d_{c b}=9.29 \mathrm{~mm}$

Normal diameter $=\frac{d_{c b}}{0.84}=\frac{9.29}{0.84}=10.93 \mathrm{~mm}$
TABLE I. MATERIAL PROPERTIES

\begin{tabular}{|c|c|c|c|c|}
\hline Sl.NO. & Materials & $\begin{array}{c}\text { Young's } \\
\text { Modulus } \\
(\boldsymbol{G P a})\end{array}$ & $\begin{array}{c}\text { Poisson's } \\
\text { ratio }\end{array}$ & $\begin{array}{c}\text { Density } \\
(\boldsymbol{k g} / \\
\left.\boldsymbol{m}^{3}\right)\end{array}$ \\
\hline 1 & $\begin{array}{c}\text { Aluminium } \\
\text { alloy-7075 }\end{array}$ & 71.7 & 0.33 & 2180 \\
\hline 2 & $\begin{array}{c}\text { Beryllium } \\
\text { alloy(25) }\end{array}$ & 125 & 0.3 & 8250 \\
\hline 3 & $\begin{array}{c}\text { Magnesium } \\
\text { alloy }\end{array}$ & 45 & 0.3 & 1810 \\
\hline 4 & $\begin{array}{c}\text { Titanium } \\
\text { alloy }\end{array}$ & 100 & 0.3 & 4480 \\
\hline
\end{tabular}

\section{MODELLING AND ANALYSIS}

From obtained dimensions 3-D model of connecting rod is developed in CATIA V5.

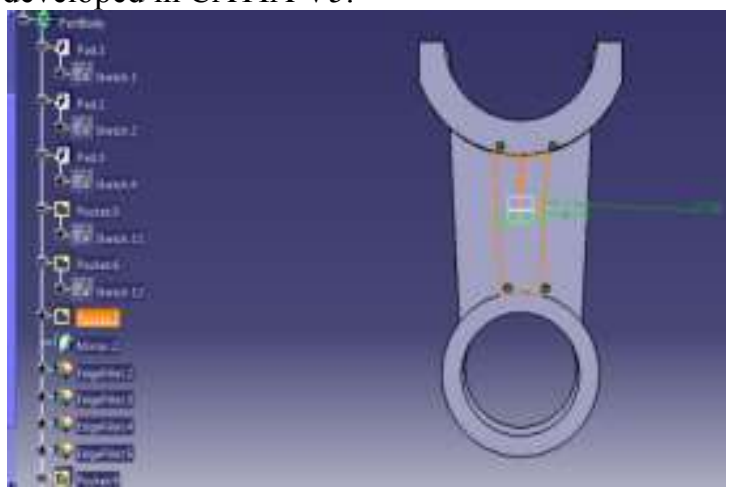

Fig 2: Modeling of connection rod

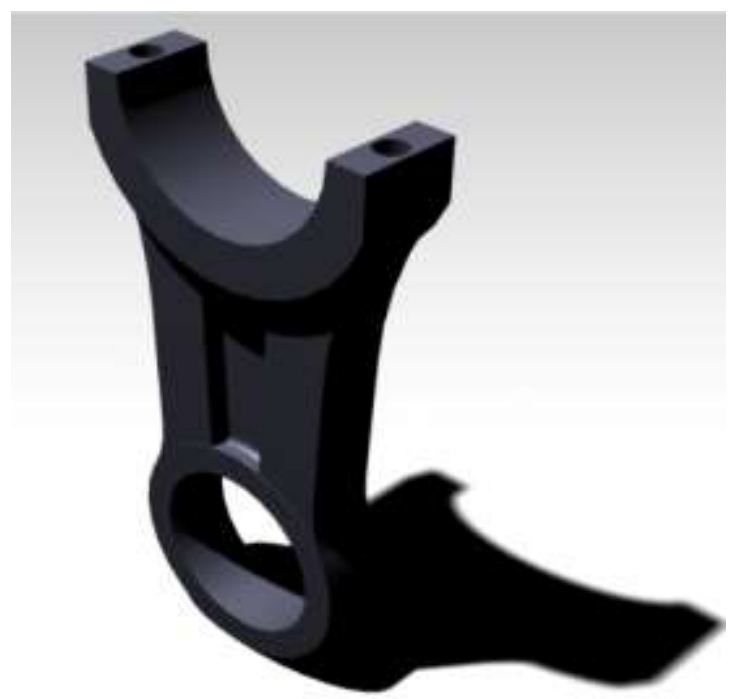

Fig 3: Complete model of connecting rod 


\section{EPRA International Journal of Research and Development (IJRD)}

Volume: 5 | Issue: 7 | July 2020

- Peer Reviewed Journal

1) Meshing

For meshing of the model, smart size was taken 6 . No. of elements were 2 and total no. of nodes are 767571 as shown in fig (4).

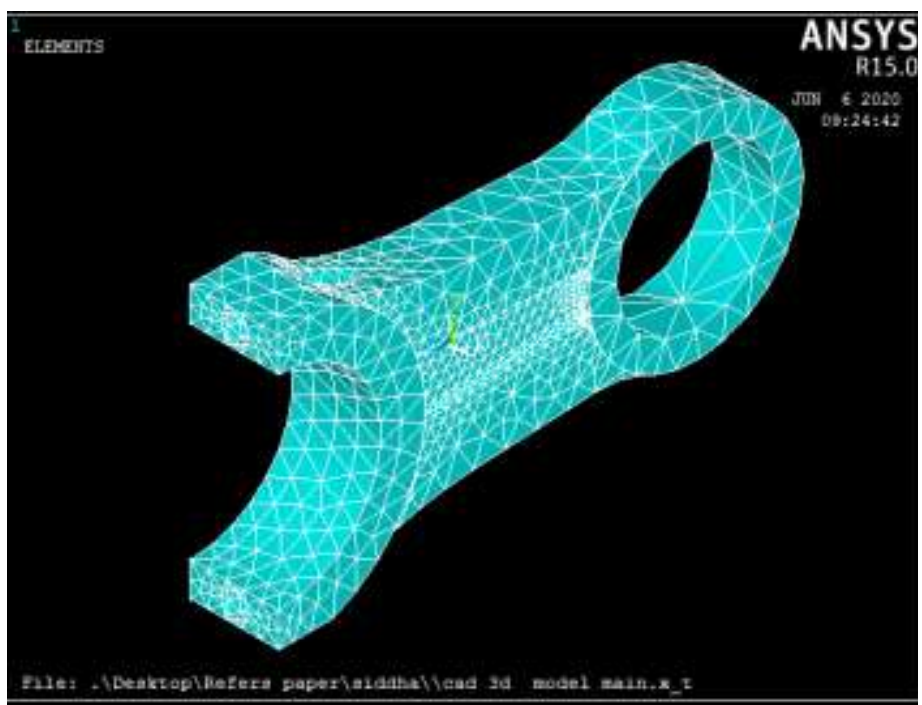

Fig 4: Meshed Model

\section{2) Apply the boundary condition}

In the ansys we applied the boundary condition. Crank end of the connecting rod fixed as shown in below fig(5). For the finite element analysis $21.11 \mathrm{Mpa}$ of pressure is applied as shown in fig(6). The pressure is applied at the piston end of connecting rod keeping crack end fixed. The maximum and minimum Von-mises stress, strain and displacement are noted from the ANSYS.

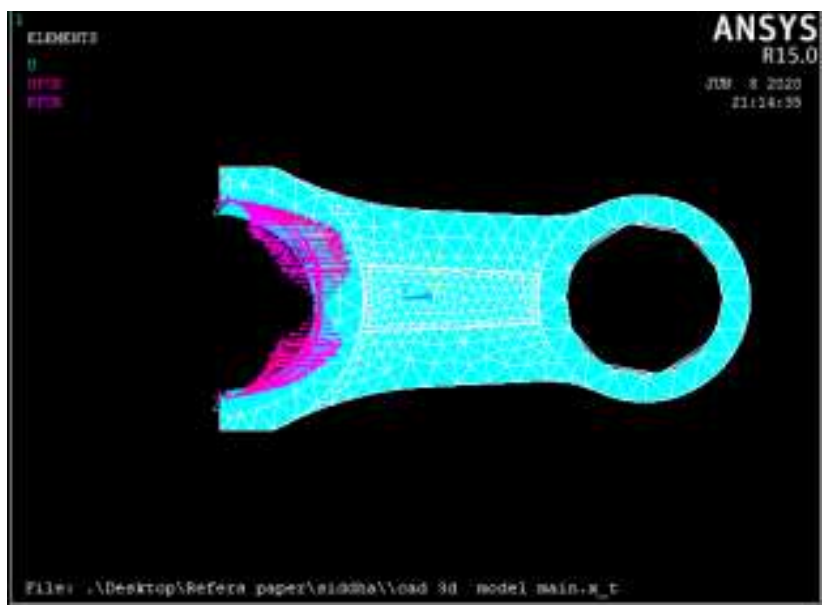

Fig 5: Crack end is fixed

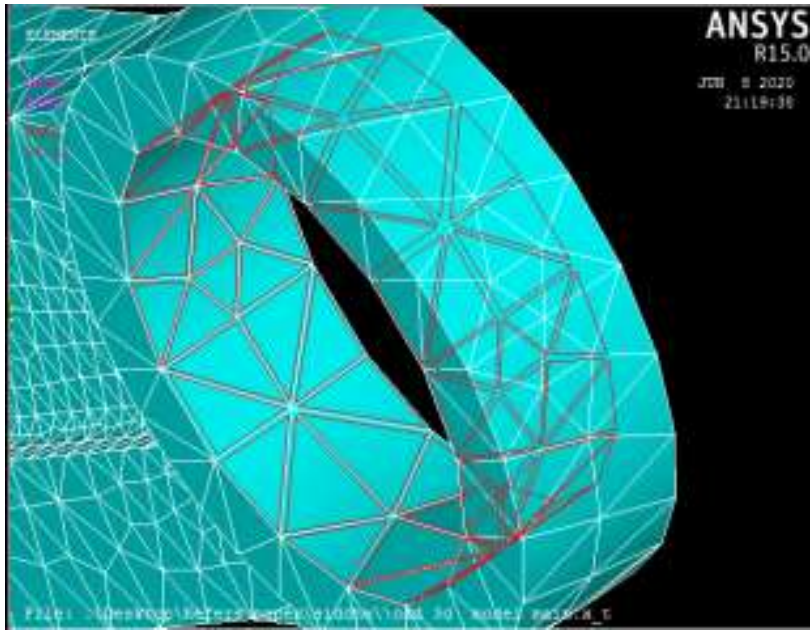

Fig 6: Pressure applied on piston end

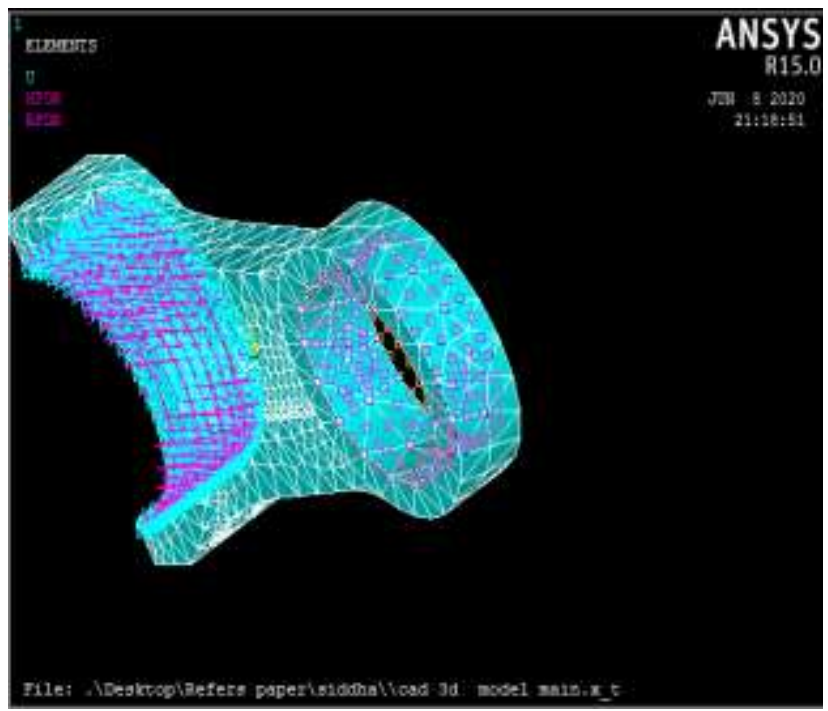

Fig 7: Fixed end and pressure applied end

\section{RESULTS AND DISCUSSION}

For FEA analysis $21.11 \mathrm{MPa}$ pressure is applied at piston end and crank end was constrained in all degrees of freedom. The maximum and minimum Von-mises stress, elastic strain and deformation were noted from ANSYS 15.0 APDL software.

Materials used for analyzing of connecting rod:

\section{Aluminium alloy-7075}

Maximum total deformation occurs at piston end of connecting rod is $0.552 \times 10^{-3} \mathrm{~mm}$ fig (8). 


\section{EPRA International Journal of Research and Development (IJRD)}

Volume: 5 | Issue: 7 | July 2020

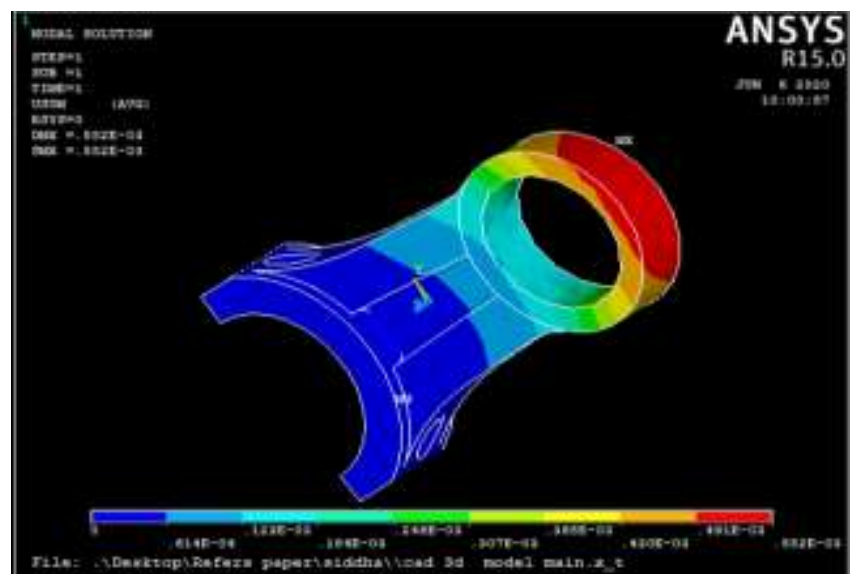

Fig 8: Deformation output of Aluminium alloy-7075

The maximum stress at piston end of connecting rod is 266.08 $\mathrm{N} / \mathrm{mm}^{2}$. The minimum stress at piston end of connecting rod is $0.251484 \mathrm{~N} / \mathrm{mm}^{2}$ fig (9).

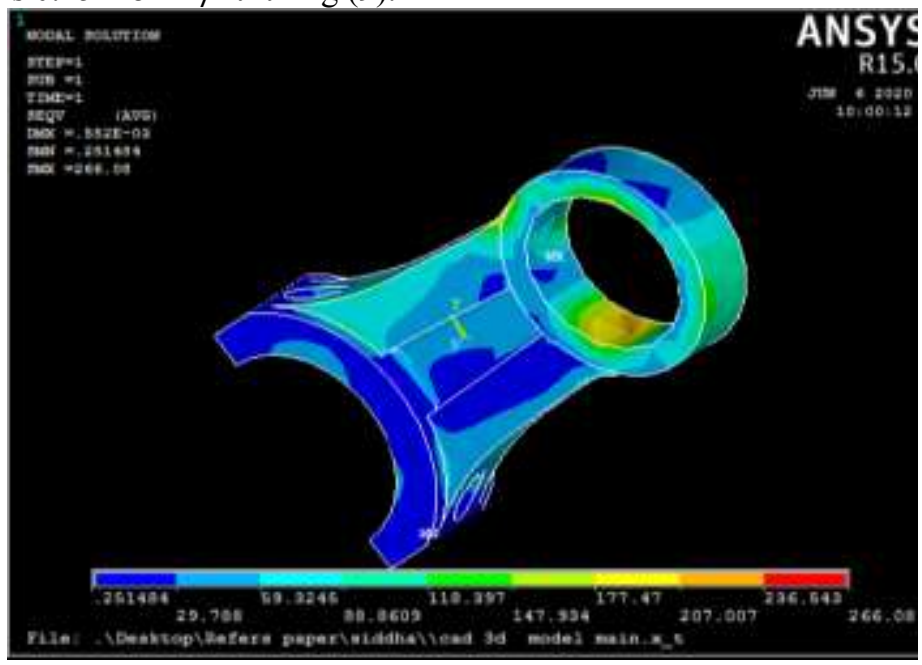

Fig 9: Von-mises stress output of aluminium alloy7075

The maximum strain at piston end of connecting rod is $0.5417 \times 10^{-2}$. The minimum strain at piston end of connecting rod is $0.538 \times 10^{-5}$ fig $(10)$.
- Peer Reviewed Journal

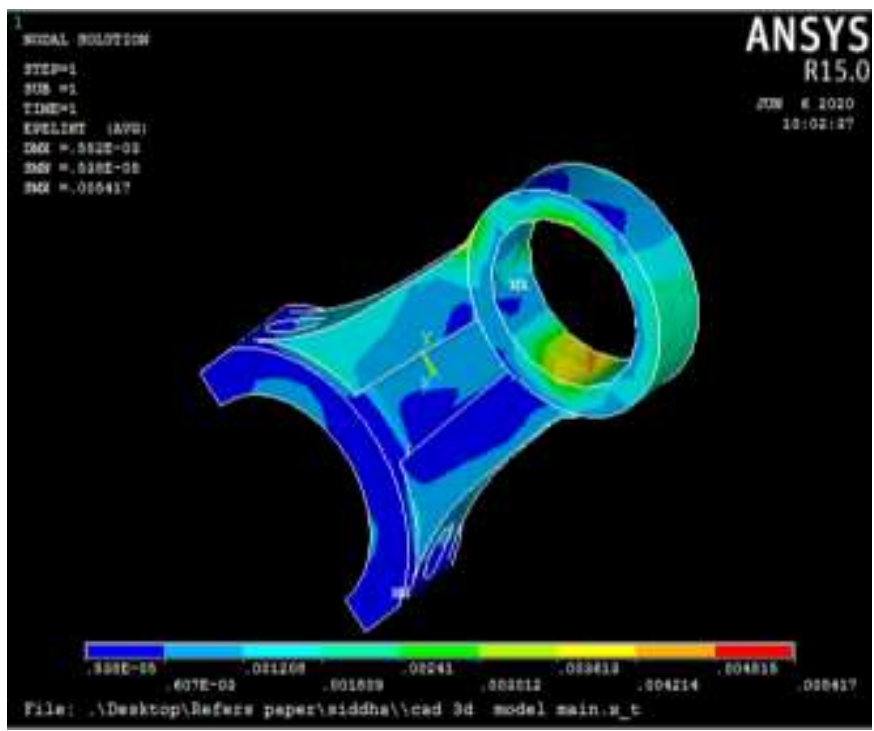

Fig 10: Strain output of Aluminium alloy-7075

2. Beryllium alloy (25)

Maximum total deformation occurs at piston end of connecting rod is $0.753 \times 10^{-4} \mathrm{~mm}$ fig (11).

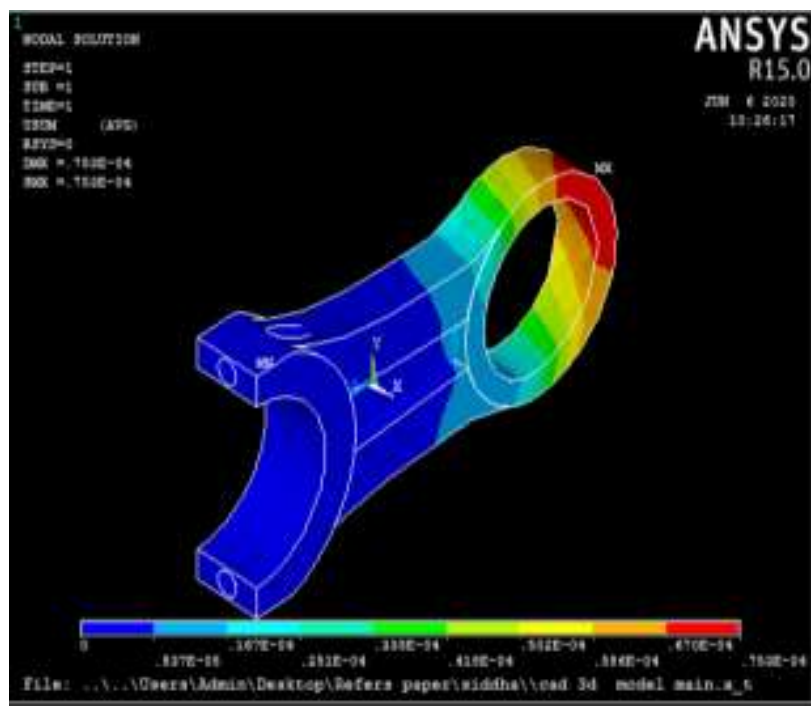

Fig 11: Deformation output of Beryllium alloy (25)

The maximum stress at piston end of connecting rod is $129.885 \mathrm{~N} / \mathrm{mm}^{2}$. The minimum stress at piston end of connecting rod is $0.019535 \mathrm{~N} / \mathrm{mm}^{2}$ fig (12). 


\section{EPRA International Journal of Research and Development (IJRD)}

Volume: 5 | Issue: 7 | July 2020

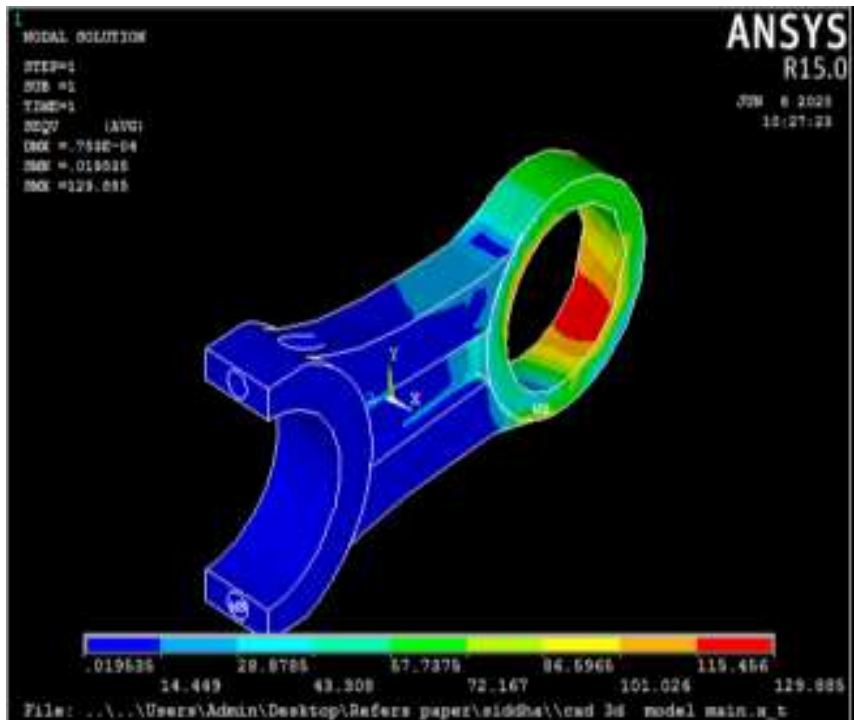

Fig 12: Von-mises stress output of Beryllium alloy(25)

The maximum strain at piston end of connecting rod is 0.001473 . The minimum strain at piston end of connecting rod

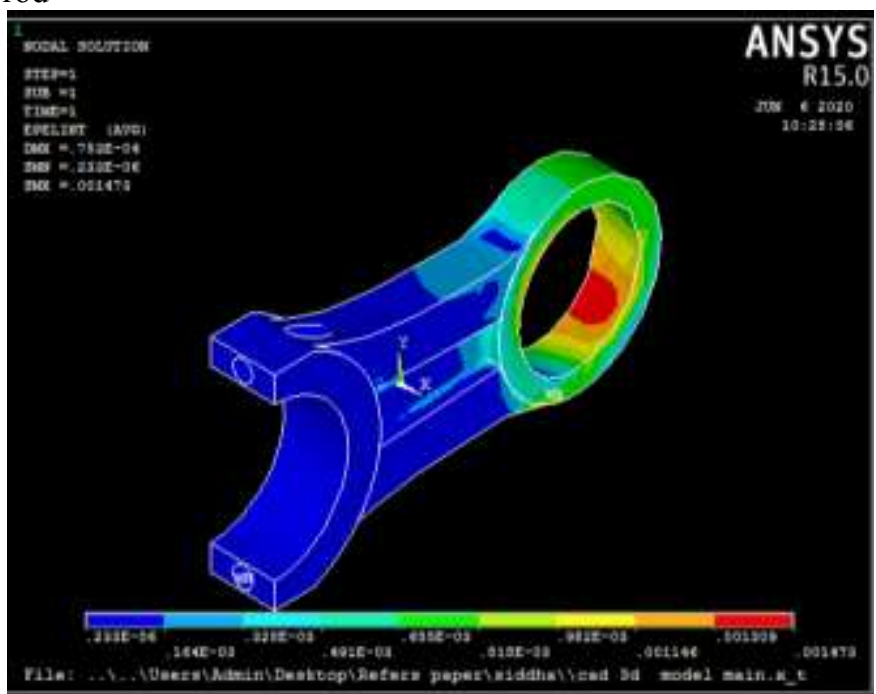

Fig 13: Strain output of Beryllium alloy(25)

3. Magnesium alloy

Maximum total deformation occurs at piston end of connecting rod is $0.954 \times 10^{-4} \mathrm{~mm}$ fig (14).
- Peer Reviewed Journal

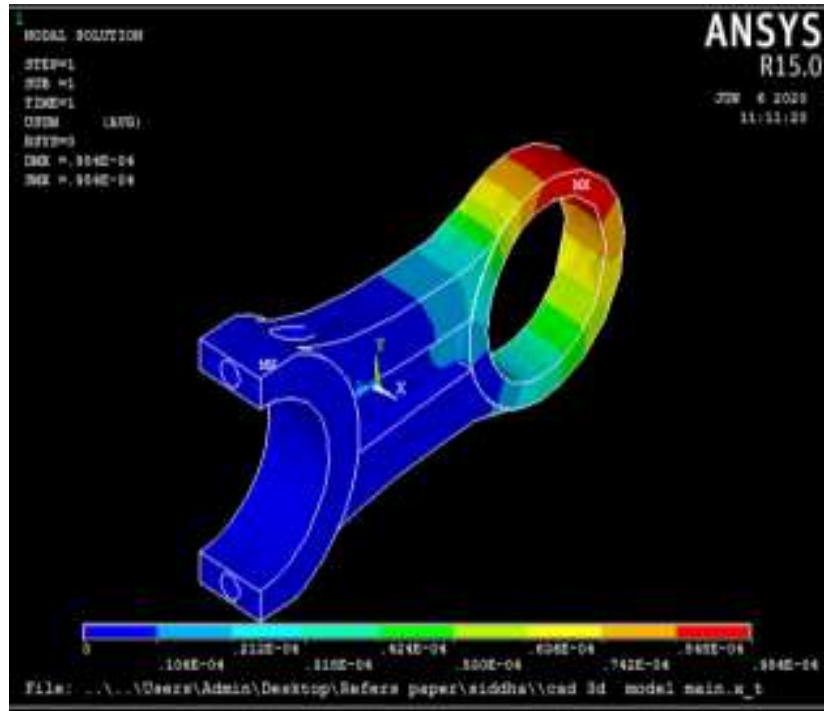

Fig 14: Deformation output of Magnesium alloy

The maximum stress at piston end of connecting rod is $98.0072 \mathrm{~N} / \mathrm{mm}^{2}$. The minimum stress at piston end of connecting rod is $0.006635 \mathrm{~N} / \mathrm{mm}^{2}$ fig (15).

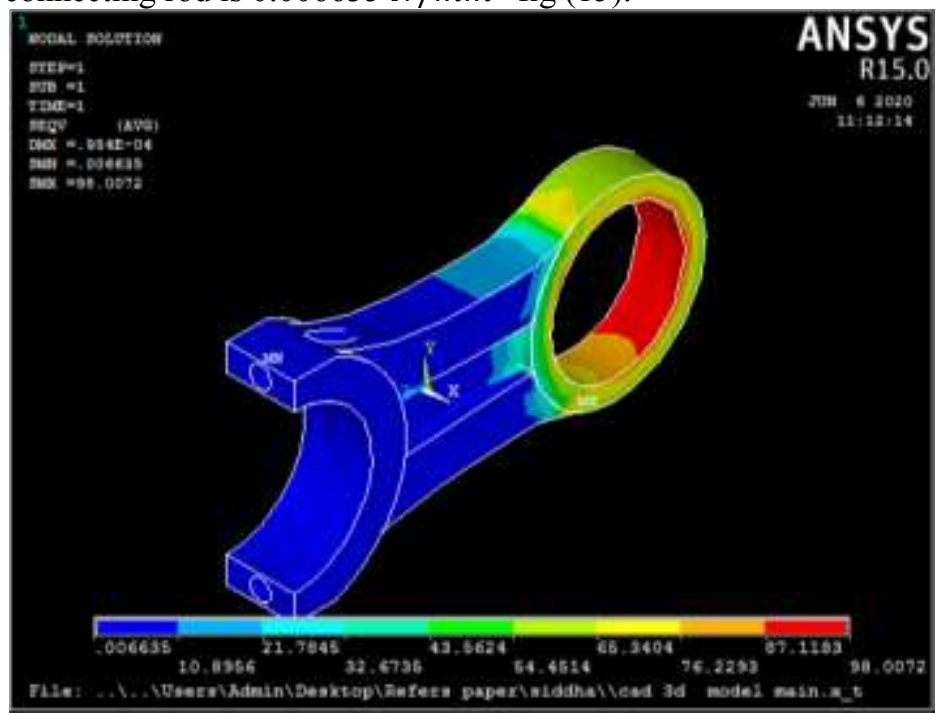

Fig 15: Von-mises stress output of Magnesium alloy

The maximum strain at piston end of connecting rod is 0.00306 . The minimum strain at piston end of connecting rod is $0.20 \times 10^{-6}$ fig (16). 


\section{EPRA International Journal of Research and Development (IJRD)}

Volume: 5 | Issue: 7 | July 2020

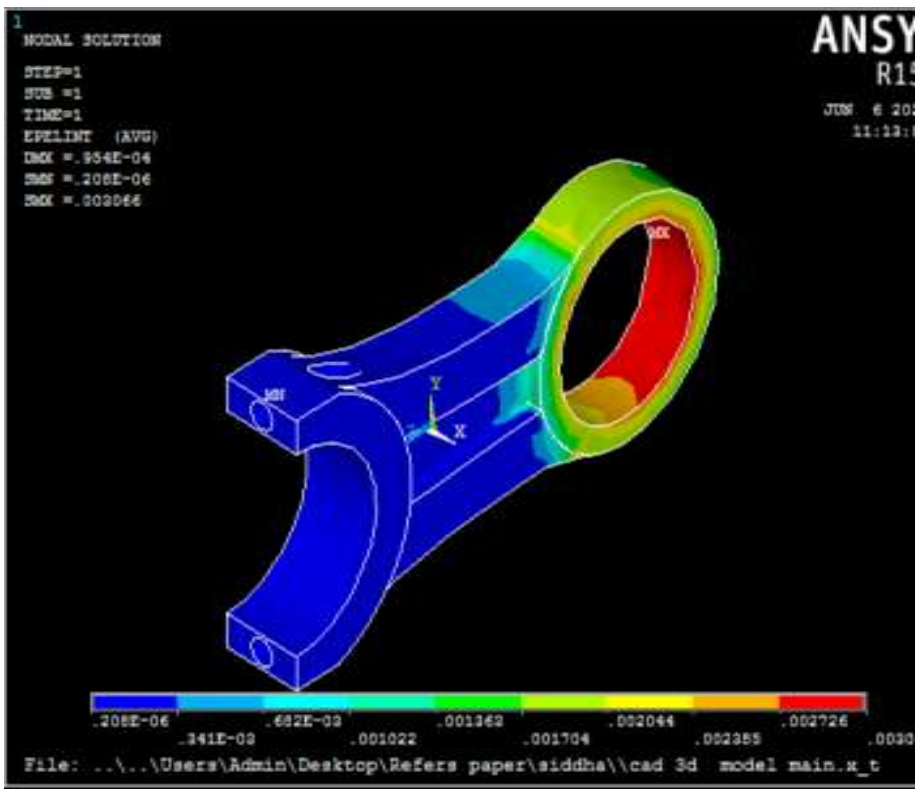

Fig 16: Strain output of Magnesium alloy

4. Titanium alloy (Ti-3Al-2.5V)

Maximum total deformation occurs at piston end of connecting rod is $0.272 \times 10^{-4} \mathrm{~mm}$ fig (17).

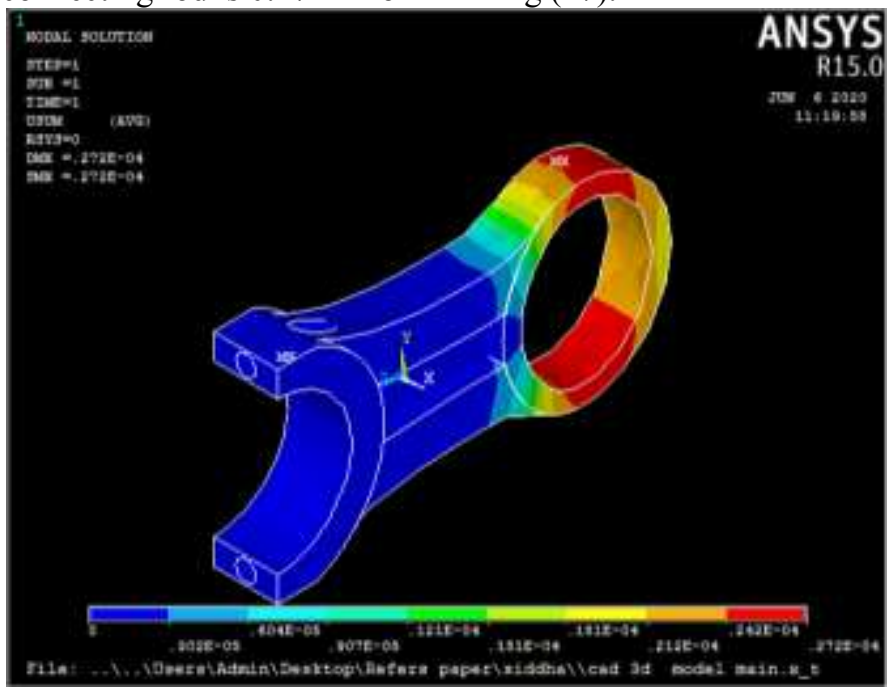

Fig 17: Deformation output of Titanium alloy

The maximum stress at piston end of connecting rod is $100.214 \mathrm{~N} / \mathrm{mm}^{2}$. The minimum stress at piston end of connecting rod is $0.0930 \times 10^{-3} \mathrm{~N} / \mathrm{mm}^{2}$ fig (18).
- Peer Reviewed Journal

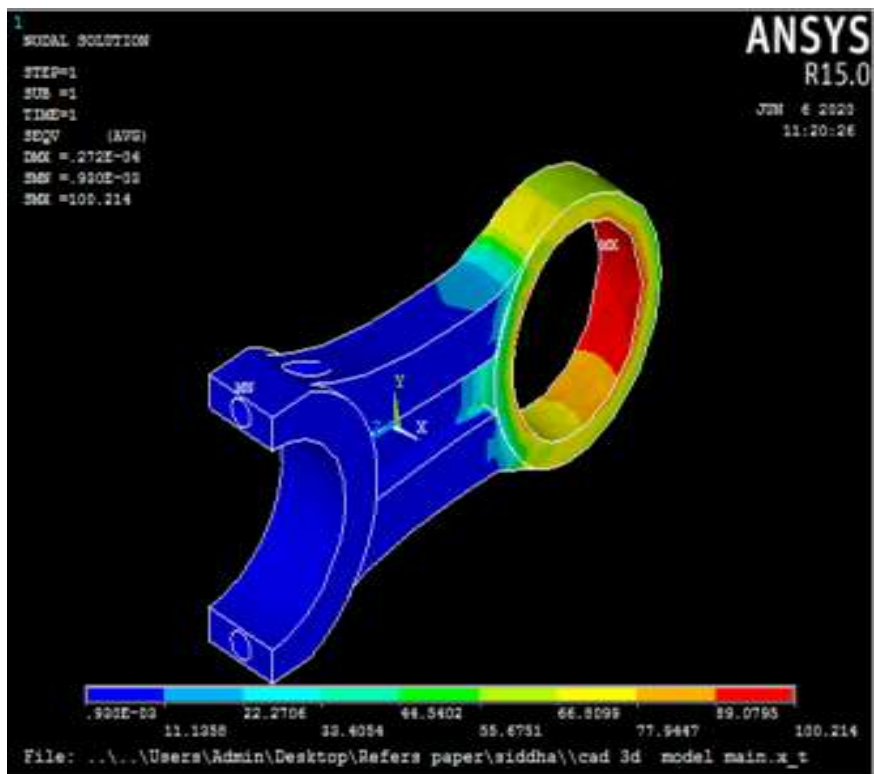

Fig 18: Von-mises stress output of Titanium alloy

The maximum strain at piston end of connecting rod is 0.001431 . The minimum strain at piston end of connecting rod is $0.139 \times 10^{-7}$ fig (19).

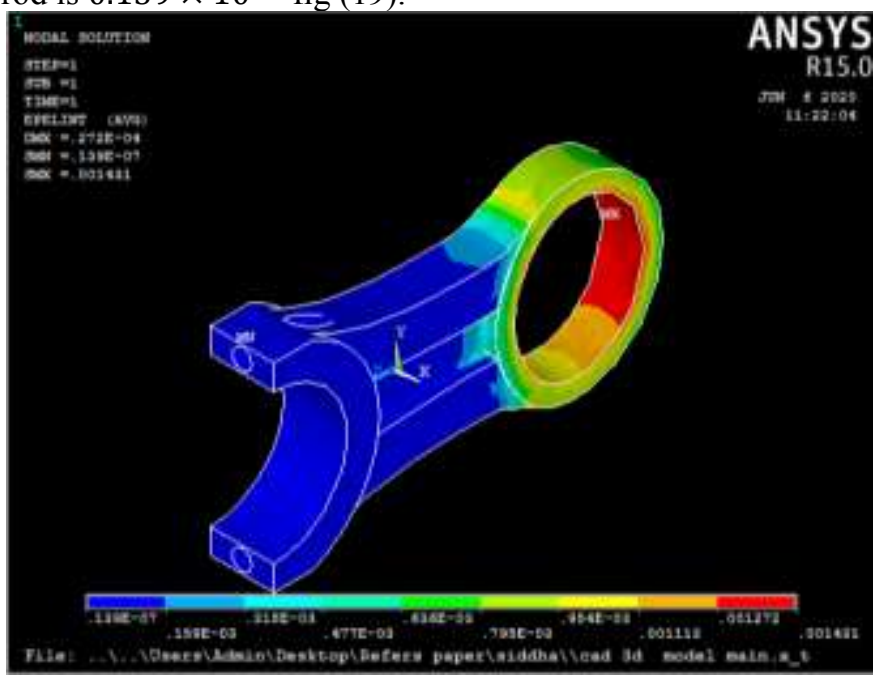

Fig 19: Strain output of Titanium alloy 


\section{EPRA International Journal of Research and Development (IJRD)}

Volume: 5 | Issue: 7 | July 2020

- Peer Reviewed Journal

3) Deformation

TABLE II. COMPARISON OF FEA RESULTS

\begin{tabular}{|l|c|c|c|c|}
\hline Sl.NO. & Materials & $\begin{array}{l}\text { Von- } \\
\text { mises } \\
\text { stress } \\
\mathbf{( N /} \\
\left.\mathbf{m m}^{\mathbf{2}}\right)\end{array}$ & $\begin{array}{l}\text { Elastic } \\
\text { Strain } \\
\text { Intensit } \\
\mathbf{y} \\
\left(\times \mathbf{1 0}^{-\mathbf{2}}\right)\end{array}$ & $\begin{array}{l}\text { Deformati } \\
\text { on } \\
\mathbf{( m m )} \\
\left(\times \mathbf{1 0}^{-4}\right)\end{array}$ \\
\hline 1 & $\begin{array}{c}\text { Aluminium } \\
\text { alloy-7075 }\end{array}$ & 266.08 & 0.5417 & 5.52 \\
\hline 2 & $\begin{array}{c}\text { Beryllium } \\
\text { alloy(25) }\end{array}$ & 129.885 & 0.1473 & 0.753 \\
\hline 3 & $\begin{array}{c}\text { Magnesium } \\
\text { alloy }\end{array}$ & 98.0072 & 0.3066 & 0.954 \\
\hline 4 & $\begin{array}{c}\text { Titaniumall } \\
\text { oy (Ti-3Al- } \\
\text { 2.5V) }\end{array}$ & 100.214 & 0.1431 & 0.272 \\
\hline
\end{tabular}

Comparison of FEA results as shown in above table is ploted in graph.

Comparison of different materials

1) Stress

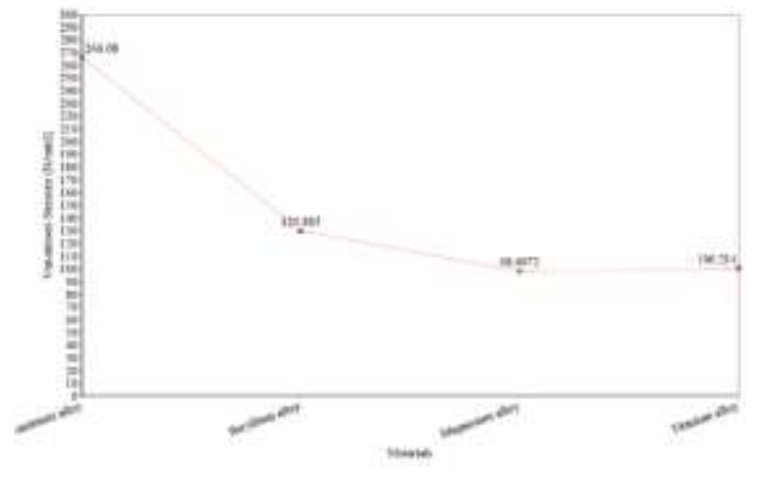

Fig 20: Stress comparison chart

2) Strain

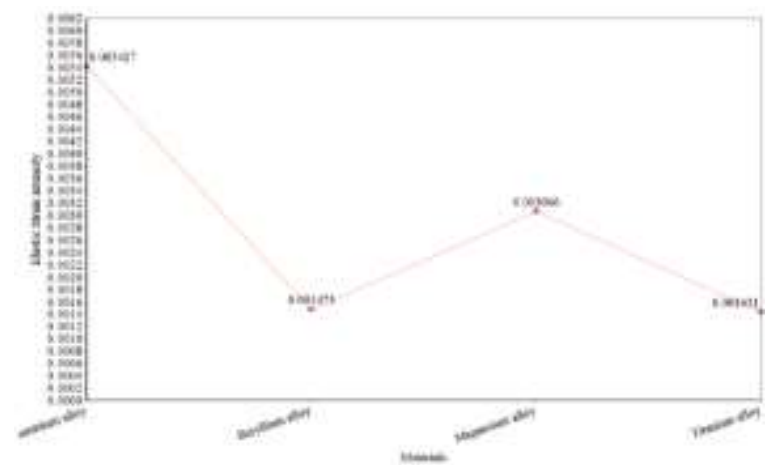

Fig 21: Strain comparison chart

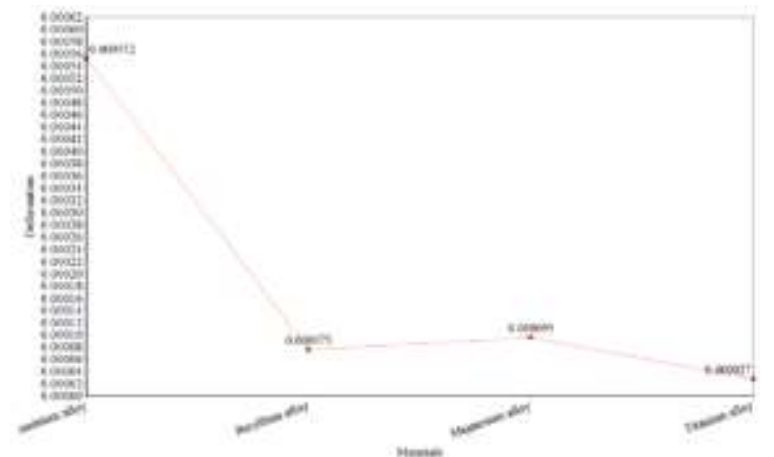

Fig 22: Deformation comparison

\section{CONCLUSION}

In this analysis the pressure on the piston head were applied and its effect on connecting rod was studied.

$>$ In the proposed approach Activa $6 \mathrm{G}$ vehicle specification has been considered for designing of connecting rod.

$>$ In CATIA V5 solid modeling of connecting rod was rendered in accordance with production drawing specification and pressure effect analysis was conducted in ANSYS 15.0 APDL for stress, strain and deformation.

$>$ In static analysis yhe crank end was fixed and piston end was under pressure, it is found that maximum stress was developed at piston end.

$>$ From above material property point of view the Magnesium alloy and Aluminium alloy-7075 are having less density compared to the Beryllium alooy(25) and Titanium alloy(Ti-3Al-2.5V).

$>$ By observation of ANSYS analysis the maximum Vonmises stress, elastic strain intensity and deformation found minimum in Magnesium alloy.

> Hence, according to study Magnesium alloy can be used for production of connecting rod in two wheelers.

\section{REFERENCES}

1. Singiresu Rao "The Finite element in engineering $4^{\text {th }}$ edition" ebook ISBN: 9780080470504, $6^{\text {th }}$ December 2004.

2. N.P.Dhoshi et.al, " Analysis of connecting rod using analytical and FEM", International journal of modern engineering research (IJMER), vol.3, ISSUE-1, ISSN: 2249-6645, JanuaryFebruary 2013.

3. Ritesh Kumar Patel 2014 " Finite element analysis pf connecting rod using CAE tools”, Master's Thesis, National Institute of Technology, Kurukshetra.

4. A Muhammad et al, "Finite Element Analysis of connecting rod in ANSYS", IOP conf.series: Materials science and engineering 736(2020) 022119.

5. Ruchir Shrivastava “ Finite Element analysis of connecting rod for two wheeler and optimization of suitable material under static load condition", International Research Journal of Engineering and Technology (IRJET), vol-04, e-ISSUE: 23950056, February 2017.

6. Gurunath $V$ Shinde et al "Stress analysis of connecting rod using FEA", Researchgate publication, February 2005.

7. Ashwini Mane et al "Finite Element Analysis and Design optimization of connecting rod", International Journal of 
Engineering Research and Application (IJERA), vol-6, ISSUE-7, ISSN: 2248-9622, July 2016.

8. K Mahadevan and Balaveera Reddy-Design Data Hand BookCBS Publication, 4th Edition, 2013.

9. Suraj Pal et al " Design Evaluation and optimization of connecting rod parameters using FEM " International Journal of Engineering and Management Research (IJEMR), vol-2, Issue-6, ISSN: 2250-0758, December-2012.

10. Pranav G Charkha et al "Analysis and optimization of connecting rod" second international conference of emerging trends in engineering and technology, December-2009. 